\title{
PENGARUH KUALITAS LAYANAN MOBILE BANKING DAN TINGKAT KEPERCAYAAN TERHADAP KEPUASAN NASABAH BANK NTB SYARIAH CABANG SUMBAWA
}

\author{
Nora Dery Sofya ${ }^{1}$, Dedy Heriwibowo ${ }^{2^{\star}}$, Rodianto ${ }^{3^{\wedge}}$ \\ 1,2Sekolah Pascasarjana Univesitas Teknologi Sumbawa \\ ${ }^{3}$ Fakultas Teknik Universitas Teknologi Sumbawa \\ "Corresponding email: nora.dery.sofya@uts.ac.id , dedyheriwibowo@gmail.com, rodianto@uts.ac.id
}

\begin{tabular}{|c|c|}
\hline & Abstrak \\
\hline $\begin{array}{l}\text { Keywords: } \\
\text { Kualitas Layanan, } \\
\text { Mobile banking, } \\
\text { Tingkat } \\
\text { Kepercayaan, } \\
\text { Kepuasan } \\
\text { Nasabah, Bank } \\
\text { Syariah }\end{array}$ & $\begin{array}{l}\text { Penelitian ini bertujuan untuk mengetahui pengaruh secara parsial dan secara simultan } \\
\text { kualitas layanan mobile banking dan tingkat kepercayaan terhadap kepuasan nasabah } \\
\text { Bank NTB Syariah Cabang Sumbawa. Penelitian ini merupakan penelitian deskriptif } \\
\text { kuantitatif. Jenis data yang digunakan, yaitu data primer yang didapatkan dari hasil } \\
\text { penyebaran kuesioner kepada para nasabah Bank NTB Syariah Cabang Sumbawa. } \\
\text { Sampel dalam penelitian adalah } 100 \text { responden yang merupakan nasabah pengguna } \\
\text { layanan mobile banking Bank NTB Syariah Cabang Sumbawa. Metode analisis data yang } \\
\text { digunakan adalah regresi linear berganda yang meliputi uji parsial, uji simultan, dan uji } \\
\text { koefisien determinasi. Hasil penelitian menunjukkan bahwa secara parsial dan simultan } \\
\text { kualitas layanan dan tingkat kepercayaan nasabah berpengaruh positif dan signifikan } \\
\text { terhadap kepuasan nasabah pengguna layanan mobile banking. Selain itu, kemampuan } \\
\text { variabel bebas dalam menjelaskan variabel terikat berdasarkan nilai Adjusted } R \text { Square } \\
\text { sebesar } 76,9 \% \text { dan sisanya sebesar } 23,1 \% \text { dipengaruhi oleh variabel lain yang tidak } \\
\text { dibahas dalam penelitian ini. }\end{array}$ \\
\hline
\end{tabular}

\section{PENDAHULUAN}

Sektor jasa keuangan merupakan sektor yang memegang peranan penting dalam meningkatkan pertumbuhan ekonomi suatu negara. Pertumbuhan ekonomi dikatakan meningkat jika kegiatan dalam perekonomian dapat menghasilkan barang dan jasa yang berdampak positif pada peningkatan kemakmuran masyarakat. Salah satu contoh sektor jasa keuangan yang memiliki peran penting sebagai sumber pendanaan yang bisa dimanfaatkan untuk meningkatkan perekonomian, yaitu sektor perbankan. Perbankan sebagai lembaga keuangan diharapakan mampu mendorong pertumbuhan ekonomi dan dapat memberikan sumbangsih terhadap pendapatan nasional yang berfungsi sebagai perantara untuk menampung dana masyarakat agar dapat disalurkan kembali untuk kegiatan perekonomian yang bersifat produktif. Perbankan di Indonesia memiliki berbagai macam jenis yang terdiri dari bank berdasarkan fungsinya, seperti Bank Sentral, Bank Umum, dan Bank Perkreditan Rakyat. Bank berdasarkan kepemilikan yang meliputi Bank Pemerintah, Bank Swasta Nasional, Bank Koperasi, dan Bank Asing. Sedangkan, bank berdasarkan statusnya dibedakan menjadi Bank Devisa dan Bank Non-Devisa. Untuk jenis bank berdasarkan kegiatan operasional dapat dibedakan menjadi Bank Konvensional dan Bank Syariah.
Bank Syariah merupakan bank yang dalamkegiatan operasionalnya tidak seperti bank konvensional, yaitu tidak menggunakan sistem bunga, namun menggunakan prinsip dasar Syariah yang sesuai dengan syariat islam. Bank NTB Syariah merupakan salah satu perbankan syariah yang ada di Indonesia. Sebagai salah satu bank syariah yang ada di Nusa Tenggara Barat, Bank NTB Syariah terus meningkatkan pelayanannya. Salah satu peningkatan pelayanan yang terus dikembangkan, yaitu layanan teknologi digital, seperti mobile banking. Layanan teknologi digital menjadi sangat penting karena dalam proses proses pemanfaatannya dapat mengakomodir kebutuhan berinteraksi antara Bank NTB Syariah dengan nasabah. Selain itu, keuntugan lain dari penggunaan layanan teknologi digital memiliki tingkat efektivitas dan efisiensi yang lebih tinggi.

Dalam penelitian ini, fokus objek penelitian yang diteliti, yaitu layanan mobile banking NTB Syariah Cabang Sumbawa. Dengan memanfaatkan mobile banking, Bank NTB Syariah dapat memberikan kesempatan kepada nasabah untuk mengakses berbagai fitur perbankan dengan mudah tanpa perlu ke kantor cabang terdekat. Oleh karena itu, nasabah tidak perlu lagi ke kantor cabang untuk mengantre dan melakukan transaksi perbankan secara konvensional. Hal ini dikarenakan mobile banking NTB Syariah sudah dilengkapi dengan 
berbagai fitur yang dibutuhkan nasabah, seperti informasi saldo, transfer, pembelian, maupun pembayaran. Dari berbagai fitur yang ditawarkan tersebut, akan sangat menguntungkan dan menarik minat nasabah untuk menggunakan layanan mobile banking.

Dengan demikian, untuk menjaga keberlangsungan dari penggunaan mobile banking oleh nasabah bank NTB Syariah Cabang Sumbawa, pihak bank harus mendengar dan mengkaji saran dan masukan sebagai umpan balik dari nasabah terkait fitur yang ditawarkan. Hal ini bisa dilakukan dengan cara menyebarkan kuesioner untuk mengetahui pengaruh kualitas layanan mobile banking dan tingkat kepercayaan terhadap kepuasan nasabah Bank NTB Syariah Cabang Sumbawa.

\section{LANDASAN TEORI}

\section{Kualitas Layanan}

Kualitas pelayanan dapat didefinisikan sebagai seberapa jauh perbedaan yang timbul antara kenyataaan dan harapan dari para pelanggan atas layanan yang diterima oleh pelanggan. Dengan demikian, kualitas pelayanan dapat diketahui dengan cara membandingkan persepsi para pelanggan atas layanan yang benar-benar diterima dan diberikan oleh penyedia jasa (Guspul, 2014: 41)

\section{Kepercayaan Nasabah}

Asas kepercayaan dalam perbankan adalah suatu asas yang menyatakan bahwa usaha bank dilandasi oleh hubungan kepercayaan antara bank sebagai penyedia layanan dan nasabahnya. Untuk terus dapat menjaga kesehatan perbankan dengan tetap memelihara dan mempertahankan kepercayaan nasabah sebagai pihak bank yang biasanya bekerja dengan dana dari masyarakat dan disimpan padanya atas dasar kepercayaan. Kepercayaan nasabah bahwa dana yang disimpan dibank dapat diambil pada waktu yang diinginkan dan sesuai dengan perjanjian yang disertai dengan imbalan, sehingga kemauan masyarakat untuk menyimpan sebagian dananya di bank dilandasi dengan asas kepercayaan. Namun, tidak menutup kemungkinan terhadap dana yang telah disimpan nasabah akan terjadi penarikan dana yang dilakukan secara bersama-sama (rush), apabila kepercayaan dari nasabah telah berkurang (Usman, 2003: 16).

\section{Kepuasan Nasabah}

Kepuasan nasabah yang diberikan pihak bank akan berimbas sangat luas bagi peningkatan keuntungan bank tersebut, sehingga apabila nasabah merasa puas maka nasabah akan (a) loyal kepada bank, (b) menggunakan produk secara berkelanjutan, (c) memberikan promosi gratis karena kualits layanan yang didapat, (d) informasi yang didapat sesuai dengan ekspektasi, (e) merasa puas terhadap pengembangan produk yang bermanfaat dan berfungsi dengan baik, dan (f) senang menggunakan produk-produk yang ditawarkan bank (Kasmir, 2004: 162-163). Dengan demikian, untuk mewujudkan kepuasan nasabah, usaha perbankan sangat bergantung pada aspek layanan (Cahyani, 2020: 35).

\section{Layanan Mobile Banking}

Layanan mobile baking bank syariah adalah pengembangan dari dua bentuk inovasi bank syariah sebelumnya, yaitu sms banking dan internet banking yang memiliki banyak kesamaan secara fungsional. Kedua berntuk teknologi informasi perbankan ini sama-sama berbasis internet. Jenisjenis layanan perbankan syariah yang diberikan dan terdapat pada mobile banking relatif sama dengan internet banking, seperti transfer dana, informasi saldo, mutase rekening, pembayaran, pembelian dan layanan lainnya (Yusmad, 2018: 79-80).

\section{Kerangka Konseptual}

Kerangka konseptual dalam penelitian pengaruh kualitas layanan mobile banking dan tingkat kepercayaan terhadap kepuasan nasabah Bank NTB Syariah Cabang Sumbawa terdiri dari tiga variabel yaitu kualitas, kepercayaan, dan kepuasan.

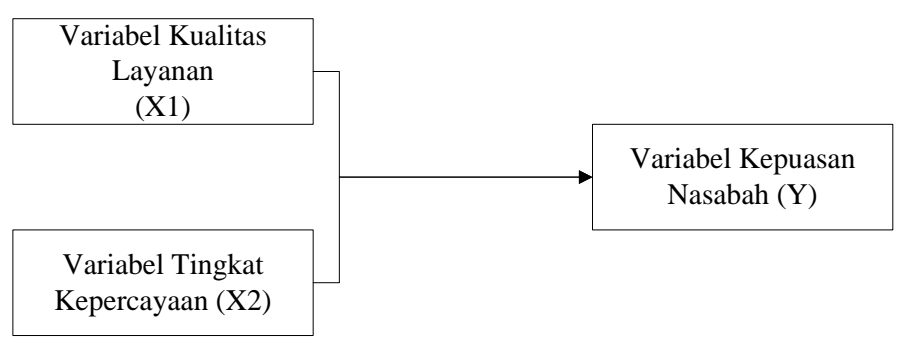

Gambar 1. Kerangka Konseptual

Sumber: Bank NTB Syariah Cabang Sumbawa diolah oleh penulis, 2020

\section{METODE PENELITIAN}

\section{Jenis Penelitian}

Jenis penelitian ini adalah penelitian kuantitaif dengan sifat penelitian deskriptif yang bertujuan untuk megetahui keterikatan variabel bebas, meliputi kualitas layanan dan tingkat kepercayaan memiliki pengaruh terhadap variabel terikat, yaitu kepuasan nasabah pada Bank NTB Syariah Cabang Sumbawa

\section{Tempat dan Waktu Penelitian}

Tempat penelitian adalah Bank NTB Syariah Cabang Sumbawa dengan waktu penelitian dari tanggal 1 Mei 2020 sampai dengan 30 Juni 2020. 


\section{Populasi dan Sampel}

Populasi terdiri dari keseluruhan pengamatan yang menjadi perhatian (Walpole \& Myers, 1995: 225). Populasi dalam penelitian ini adalah masyarakat yang berada di Kabupaten Sumbawa dan mmenjadi nasabah di Bank NTB Syariah Cabang Sumbawa. Teknik pengambilan sampel yang digunakan dalam penelitian ini menggunakan pendekatan Slovin, sehingga pengambilan sampel dapat dilakukan dengan tepat dan dapat mewakili populasi (Riyanto \& Hatmawan, 2020:12). Pendekatan pengambilan sampel berdasarkan slovin dirumuskan sebagai berikut:

$$
n=\frac{N}{1+N e^{2}}
$$

Keterangan:

$\mathrm{n} \quad=$ Jumlah sampel

$\mathrm{N}=$ Total populasi

$\mathrm{e}=$ Tingkat kesalahan dalam pengambilan sampel (10\%)

Berdasarkan rumus tersebut, maka sampel yang dapat diambil dalam penelitian pengaruh kualitas layanan mobile banking dan tingkat kepercayaan terhadap kepuasan nasabah Bank NTB Syariah Cabang Sumbawa sebagai berikut:

$$
\begin{aligned}
& n=\frac{972}{1+\left(972 \times 0,1^{2}\right)} \\
& n=\frac{972}{1+(972 \times 0,01)} \\
& n=\frac{972}{1+9,72} \\
& n=\frac{972}{10,72} \\
& n=90,67 \text { dibulatkan menjadi } 91
\end{aligned}
$$

Berdasarkan hasil dari perhitungan menggunakan rumus slovin, maka jumlah sampel yang digunakan dalam peneletian ini adalah 91 responden. Agar penelitian ini menjadi lebih efektif, jumlah sampel yang diambil adalah 100 responden.

\section{Metode Analisis}

Metode analisis data yang digunakan, yaitu uji validitas dan realibilitas pada instrument penelitian, uji asumsi klasik, uji regresi linear berganda, uji F, uji t dan uji koefisien determinasi. Fokus yang dibahas dalam pembahasan, yaitu uji regresi linear berganda meliputi uji $\mathrm{F}$, uji t dan uji koefisien determinasi.

\section{HASIL DAN PEMBAHASAN}

\section{Analisis Koefisien Regresi}

Hasil analisis dengan regresi berganda

\begin{tabular}{|c|c|c|c|c|c|c|}
\hline \multicolumn{7}{|c|}{ Coefficients $^{\mathbf{a}}$} \\
\hline \multirow[t]{2}{*}{ Model } & & \multicolumn{2}{|c|}{$\begin{array}{c}\text { Unstandardized } \\
\text { Coefficients }\end{array}$} & \multirow{2}{*}{$\begin{array}{r}\text { Standar } \\
\text {-dized } \\
\text { Coeffi- } \\
\text { cients } \\
\text { Beta }\end{array}$} & \multicolumn{2}{|c|}{$\begin{array}{c}\text { Collinearity } \\
\text { Statistics }\end{array}$} \\
\hline & & B & $\begin{array}{l}\text { Std. } \\
\text { Error }\end{array}$ & & $\begin{array}{l}\text { Tole- } \\
\text { rance }\end{array}$ & VIF \\
\hline \multirow[t]{3}{*}{1} & (Constant) & 1.383 & .844 & & & \\
\hline & $\begin{array}{l}\text { Kualitas } \\
\text { Layanan }\end{array}$ & .167 & .057 & .337 & .174 & 5.735 \\
\hline & $\begin{array}{l}\text { Tingkat } \\
\text { Kepercayaan }\end{array}$ & .454 & .093 & .562 & .174 & 5.735 \\
\hline
\end{tabular}
yang meliputi variabel bebas kualitas layanan mobile banking dan tingkat kepercayaan terhadap variabel terikat kepuasan nasabah, dapat dilihat pada tabel berikut:

Tabel 1. Hasil Koefisien Regresi

Sumber: Hasil Olahan Data, 2020

Berdasarkan analisis data yang dilakukan pada Tabel 1, maka diperoleh persamaan regresi, yaitu $\mathrm{Y}=1,38+0,16 \mathrm{X}_{1}+0,45 \mathrm{X}_{2}$ menggambarkan bahwa variabel bebas kualitas layanan $\left(\mathrm{X}_{1}\right)$ dan tingkat kepercayaan nasabah $\left(\mathrm{X}_{2}\right)$ dalam model regresi dapat dinyatakan jika satu variabel bebas berubah sebesar nilai koefisien (b) dari nilai variabel bebas tersebut. Dari persamaan di atas dapat dilihat, sebagai berikut:

1) Nilai 1,38 pada konstanta $(\alpha)$ memberikan pengertian bahwa jika variabel kualitas layanan $\left(\mathrm{X}_{1}\right)$ dan variabel tingkat kepercayaan $\left(\mathrm{X}_{2}\right)$ secara simultan atau bersama-sama tidak mengalami perubahan atau sama dengan nol (0) maka besarnya kepuasan nasabah (Y) sebesar 1,38 satuan.

2) Jika nilai $b_{1}$ yang merupakan koefisien regresi dari variabel kualitas layananan $\left(\mathrm{X}_{1}\right)$ dengan nilai 0,16 maka mempunyai pengaruh positif terhadap variabel terikat kepuasan nasabah (Y), serta mempunyai arti bahwa jika variabel kualitas layanan $\left(\mathrm{X}_{1}\right)$ bertambah 1 satuan, maka variabel kepuasan nasabah (Y) juga akan mengalami kenaikkan sebesar 0,16 satuan dengan asumsi variabel lain tetap konstan.

3) Jika nilai $b_{2}$ yang merupakan koefisien regresi dari variabel tingkat kerpercayaan $\left(\mathrm{X}_{2}\right)$ mempunyai nilai sebesar 0,45 yang artinya mempunyai pengaruh positif terhadap varibael terikat kepuasan nasabah (Y), serta mempunyai arti bahwa jika variabel tingkat kepercayaan $\left(\mathrm{X}_{2}\right)$ bertambah 1 satuan, maka kepuasan nasabah (Y) akan mengalami kenaikan sebesar 0,45 satuan dengan asumsi variabel lain tetap konstan.

Berdasarkan persamaan regresi di atas, maka koefisien regresi dari kedua variabel bebas yaitu kualitas layanan dan tingkat kepercayaan menunjukkan nilai positif. Hal ini, dapat diartikan bahwa variabel kualitas layanan dan tingkat kepercayaan mempunyai hubungan yang positif terhadap variabel kepuasan nasabah. Dari 
kedua variabel bebas yang memberikan pengaruh dominan adalah variabel tingkat kepercayaan dengan koefisien regresi sebesar 0,45 .

\section{Uji Signifikansi Parsial (Uji t)}

Uji parsial (uji t) merupakan pengujian yang digunakan untuk menunjukkan pengaruh satu variabel bebas terhadap variabel terikat.

Tabel 2. Uji t Regresi Linear Berganda Coefficients

\begin{tabular}{|c|c|c|c|c|c|c|}
\hline \multirow[t]{2}{*}{ Model } & & \multicolumn{2}{|c|}{$\begin{array}{c}\text { Unstandardized } \\
\text { Coefficients } \\
\text { Std. }\end{array}$} & $\begin{array}{l}\text { Standar- } \\
\text { dized } \\
\text { Coeffi- } \\
\text { cients }\end{array}$ & \multirow[t]{2}{*}{$\mathrm{t}$} & \multirow[t]{2}{*}{ Sig. } \\
\hline & & B & Error & Beta & & \\
\hline 1 & (Constant) & 1,383 & 0,844 & & 1,639 & 0,105 \\
\hline & Kualitas & 0,167 & 0,057 & 0,337 & 2,910 & 0,004 \\
\hline & $\begin{array}{l}\text { Tingkat } \\
\text { Keperca- } \\
\text { yaan }\end{array}$ & 0,454 & 0,093 & 0,562 & 4,859 & 0,000 \\
\hline
\end{tabular}

a. Dependent Variable: Kepuasan

Sumber: Hasil Olahan Data, 2020

Variabel kualitas layanan $\left(\mathrm{X}_{1}\right)$ berpengaruh secara positif dan signifikan terhadap kepuasan nasabah pada pengguna layanan mobile banking Bank NTB Syariah Cabang Sumbawa. Hal ini bisa dilihat dari nilai signifikan kualitas layanan 0,004< 0,05 .

Berdasarkan nilai dari Tabel 2, dapat dilihat variabel bebas tingkat kepercayaan $\left(\mathrm{X}_{2}\right)$ dengan nilai $0,00<0,05$. Oleh karena itu, variabel tingkat kepercayaan $\left(\mathrm{X}_{2}\right)$ berpengaruh secara positif dan signifikan terhadap variabel kepuasan nasabah pada penguna layanan mobile banking Bank NTB Syariah Cabang Sumbawa. Dengan adanya analisis ini, dapat menjadi indikator untuk mempertahankan kualitas layanan sehingga dapat meningkatkan kepercayaan terhadap kepuasan nasabah pengguna layanan mobile banking.

\section{Uji Signifikansi Simultan (Uji F)}

Uji simultan (uji F) dilakukan dengan membandingkan signifikansi nilai dari $F_{\text {hitung }}>F_{\text {tabel, }}$ sehingga menunjukkan semua variabel bebas yang dimasukkan ke dalam model regresi berpengaruh secara bersama-sama terhadap variabel terikat.

Tabel 3. Uji F Regresi Linear Berganda

$$
\text { ANOVA }^{\mathrm{a}}
$$

\begin{tabular}{clrrrrr}
\hline \multirow{2}{*}{ Model } & & $\begin{array}{c}\text { Sum of } \\
\text { Squares }\end{array}$ & df & $\begin{array}{c}\text { Mean } \\
\text { Square }\end{array}$ & F & Sig. \\
\hline \multirow{2}{*}{1} & Regression & 360,133 & 2 & 180,066 & 165,673 & $.000^{\mathrm{b}}$ \\
& Residual & 105,427 & 97 & 1,087 & & \\
& Total & 465,560 & 99 & & & \\
\hline
\end{tabular}

a. Dependent Variable: Kepuasan

b. Predictors: (Constant), Kepercayaan, Kualitas

Sumber: Hasil Olahan Data, 2020

Berdasarkan hasil pengujian pada Tabel 3, dapat dilihat pada nilai $F_{\text {hitung }}$ sebesar 165,673 dengan nilai $F_{\text {tabel }}$ adalah 3,09 sehingga nilai $F_{\text {hitung }}>$ $F_{\text {tabel }}$ atau 165,673 > 3,09. Selain itu, tabel uji $F$ regresi linear berganda dengan tingkat signifikan $0,00<0,05$, maka dapat disimpulkan bahwa variabel bebas kualitas layanan $\left(\mathrm{X}_{1}\right)$ dan variabel tingkat kepercayaan $\left(\mathrm{X}_{2}\right)$ secara bersama-sama berpengaruh positif dan signifikan terhadap kepuasan nasabah pengguna layanan mobile banking Cabang Sumbawa.

\section{Uji Koefisien Determinasi $\left(\mathbf{R}^{2}\right)$}

Uji koefisein determinasi $\left(\mathrm{R}^{2}\right)$ bertujuan untuk mengukur komponen model dalam menerangkan variasi variabel terikat.

\section{Tabel 4. Uji $\mathbf{R}^{2}$ Regresi Linear Berganda} Model Summary

\begin{tabular}{|c|c|c|c|c|}
\hline Model & $\mathrm{R}$ & $\begin{array}{c}\mathrm{R} \\
\text { Square }\end{array}$ & $\begin{array}{c}\text { Adjusted } \\
\text { R } \\
\text { Square }\end{array}$ & $\begin{array}{l}\text { Std. Error of } \\
\text { the Estimate }\end{array}$ \\
\hline 1 & $.880^{\mathrm{a}}$ & 0,774 & 0,769 & 1,043 \\
\hline
\end{tabular}

Sumber: Hasil Olahan Data, 2020

Berdasarkan Tabel 4, dapat diketahui bahwa nilai koefisien determinasi yang terdapat pada nilai Adjusted R Square sebesar 0,769. Hal ini membuktikan bahwa kemampuan variabel bebas dalam menjelaskan variabel terikat adalah sebesar $76,9 \%$. Sisanya $23,1 \%$ dijelaskan oleh variabel lain yang tidak dibahas dalam penelitian ini.

\section{PEMBAHASAN}

\section{Pengaruh Kualitas Layanan Mobile Banking Terhadap Kepuasan Nasabah}

Hasil penelitian menunjukkan bahwa koefisien beta unstandardized variabel kualitas layanan mobile banking sebesar 0,16 dan (sig) t sebesar 0,004. Berdasarkan hasil analisis menunjukan bahwa kualitas layanan mobile banking berpengaruh positif dan signifikan terhadap kepuasan nasabah bank NTB Syariah Cabang Sumbawa.

Hasil analisis menunjukkan bahwa beberapa faktor yang memengaruhi kualitas layanan terhadap kepuasan nasabah, seperti layanan mobile banking NTB Syariah mudah digunakan ketika melakukan transaksi, layanan mobile banking dapat diakses dengan cepat. Selain itu, dengan menggunakan layanan mobile banking dapat mengatasi transaksi yang mendesak, sehingga 
nasabah dapat menghemat waktu transaksi. Faktor lain yang memengaruhi kualitas layanan mobile banking terhadap kepuasan nasabah, yaitu fitur dan informasi yang disediakan sesuai dengan kebutuhan nasabah. Hal ini dapat diartikan bahwa semakin baik kualitas layanan mobile banking yang diberikan oleh Bank NTB Syariah selaku penyedia jasa, maka nasabah akan semakin senang menggunakan layanan tersebut.

\section{Pengaruh Tingkat Kepercayaan Terhadap Kepuasan Nasabah}

Hasil penelitian menunjukkan bahwa koefisien beta unstandardized variabel tingkat kepercayaan sebesar 0,45 dan (sig) t sebesar 0,000. Hasil analisis menunjukkan bahwa beberapa faktor memengaruhi tingkat kepercayaan ketika layanan mobile banking NTB Syariah dapat memenuhi kebutuhan nasabah dan menjaga kerahasiaan data nasabah. Berdasarkan hasil analisis tersebut, menunjukan bahwa tingkat kerpercayaan berpengaruh positif dan signifikan terhadap kepuasan nasabah bank NTB Syariah Cabang Sumbawa.

Pengaruh Kualitas Layanan Mobile Banking dan Tingkat Kepercayaan Terhadap Kepuasan Nasabah

Bank NTB Syariah Cabang Sumbawa sebagai peneyedia jasa harus dapat mempertahanakan dan meningkatkan kualitas layanan yang terdiri dari pemenuhan produk oleh penyedia layanan sehingga dapat memberikan layanan secara tepat waktu, kemampuan penyedia layanan secara akurat sehingga dapat diandalakan, dan jaminan bahwa data dan transaksi pelanggan aman. Dengan mempertahankan dan meingkatkan kualitas layanan maka akan menimbulkan tingkat kepercayaan nasabah terhadap layanan mobile banking. Sehingga, apabila tingkat kepercayaan nasabah sudah baik terhadap layanan tersebut, maka kepuasan nasabah akan dirasakan dengan baik pula.

Hasil penelitian ini, sesuai dengan hasil penelitian uji simultan yang menunjukkan nilai $F_{\text {hitung }}$ sebesar 165,673 dengan nilai $F_{\text {tabel }}$ adalah 3,09 sehingga nilai $F_{\text {hitung }}>F_{\text {tabel }}$ atau 165,673>3,09. Selain itu, tabel uji F regresi linear berganda dengan tingkat signifikan $0,00<0,05$, maka dapat disimpulkan bahwa variabel bebas kualitas layanan $\left(\mathrm{X}_{1}\right)$ dan variabel tingkat kepercayaan nasabah $\left(\mathrm{X}_{2}\right)$ secara bersama-sama berpengaruh positif dan signifikan terhadap kepuasan nasabah pengguna layanan mobile banking Cabang Sumbawa.

\section{PENUTUP}

\section{Kesimpulan}

Berdasarkan analisis dan pembahasan pada bab sebelumnya, maka simpulan dari hasil penelitian tentang pengaruh kualitas layanan mobile banking dan tingkat kepercayaan terhadap kepuasan nasabah Bank NTB Syariah Cabang Sumbawa, yaitu secara parsial dan secara simultan kualitas layanan serta tingkat kepercayaan nasabah berpengaruh positif dan signifikan terhadap kepuasan nasabah pengguna layanan mobile banking. Selain itu, kemampuan variabel bebas dalam menjelaskan variabel terikat berdasarkan nilai Adjusted $R$ Square sebesar $76,9 \%$ dan sisanya sebesar $23,1 \%$ dipengaruhi variabel lain yang tidak dibahas dalam penelitian ini.

\section{Saran}

Berdasarkan kesimpulan di atas, Bank NTB Syariah Cabang Sumbawa sebagai penyedia jasa perlu meningkatkan kualitas layanan dan tingkat kepercayaan, sehingga bisa meningkatkan kepuasan nasabah pengguna layanann mobile banking. Dengan demikian, untuk mendukung hal tersebut, penelitian berikutnya dapat menambahkan aspek penelitian yang lebih luas, sehingga bisa mendapatkan hasil yang lebih spesifik terhadap variabel-variabel yang ada.

\section{REFERENSI}

Bank NTB Syariah. 2020. Sejarah Bank NTB Syariah. Tanggal Akses: 28 Januari 2020, dari https://www.bankntbsyariah.co.id/Perusahaan /tentangBankNTBSyariah/sejarah-bank-ntbsyarah.

Bungin. Prof. Dr. H.M. B. (2017). Metodologi Penelitian Kuantitatif (Komunikasi, Ekonomi, dan Kebijakan Publik Serta ilmu Sosial). Jakarta: Kencana.

Cahyani. P. D. \& Alvianto. A. (2020). "Pengaruh Kualitas Layanan, Kualitas Produk, Dan Pemasaran Spiritual Terhadap Kepuasan Nasabah (Komparasi Bank BNI Syariah Kantor Cabang Yogyakarta Dan Purwokerto”. Jurnal Islamadina. Vol 21. No. 1. Tanggal Akses: 11 Mei 2020.

Ghozali. I. 2013. Aplikasi Analisis Multivariate dengan Program IBM SPSS 21. Semarang: BP UNDIP.

Guspul. A. (2014). "Pengaruh Kualitas Pelayanan Dan Kepercayaan Terhadap Kepuasan Nasabah (Studi Kasus Pada nasabah Kospin Jasa Cabang Wonosobo)". Jurnal PPKM UNSIQ. Tanggal Akses: 14 Mei 2020.

Ismail. Drs, M.BA., Ak. (2011). Perbankan Syariah. Jakarta: Kencana Prenadamedia Group.

Kasmir, S.E., M.M. (2004). Pemasaran Bank. Jakarta: Kencana Prenadamedia Group. 
Riyanto. S \& Hatmawan. A. A. (2020). Metode Riset Penelitian Kuantitatif Penelitian Di Bidang Manajemen, Teknik, Pendidikan Dan Eksperimen. Yogyakarta: DeePublish CV Budi Utama.

Thalia. C. M. dkk. (2018). "Pengaruh Kepercayaan dan Kualitas Layanan Terhadap Kepuasan Nasabah PT. Bank Sulutgo”. Jurnal EMBA. Vol. 6 No. 3 Tanggal Akses: 7 Juli 2020

Sicillia. M \& Yazid. A. (2020). "Analisis Digital Banking dan Kualitas Pelayanan Terhadapa Kepuasan Nasabah Pada Sebuah Bank
Swasta”. Jurnal Pemasaran Kompetitif. Vol. 3 No.2. Tanggal Akses: 11 Mei 2020.

Usman. R. S.H. (2003). Aspek-Aspek Hukum Perbankan Di Indoensia. Jakarta: PT Gramedia Pustaka Utama.

Walpole. R.E \& Myers. R.H. (1995). Ilmu Peluang dan Statistika untuk Insinyur dan Ilmuan. Bandung: Penerbit ITB.

Yusmad. M.A. (2018). Aspek Hukum Perbankan Syariah dari Teori Ke Praktik. Yogyakarta. Deepublish CV Budi Utama. 